\title{
Nanik
}

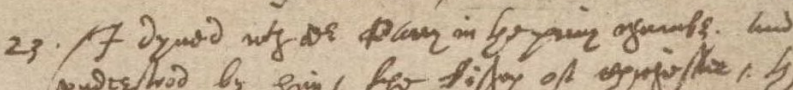

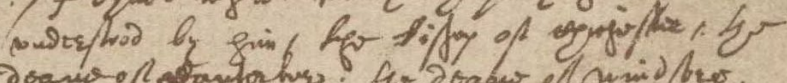

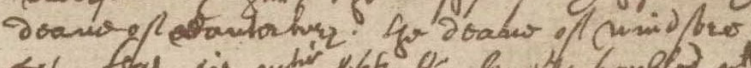

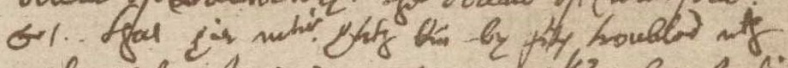

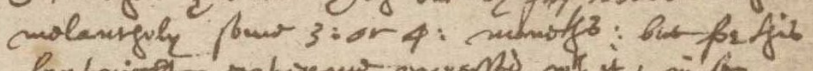

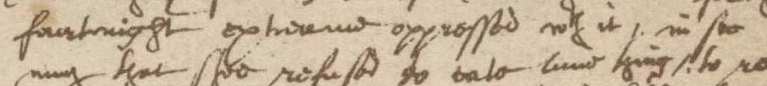

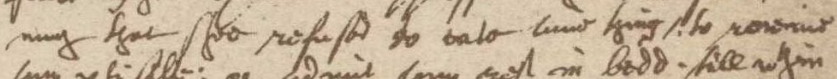

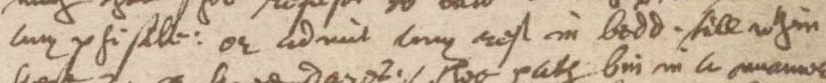

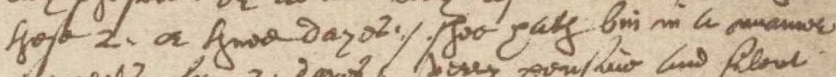

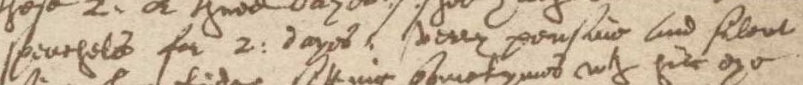

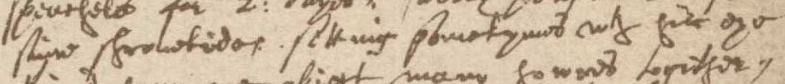

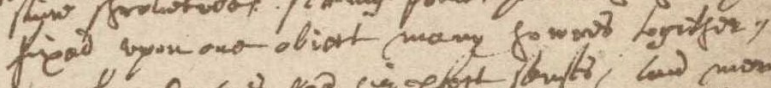

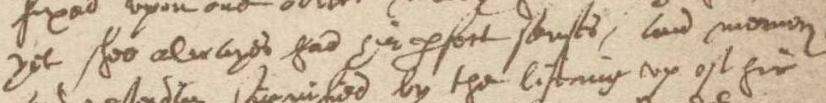

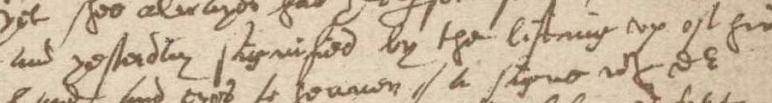

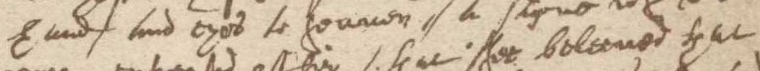

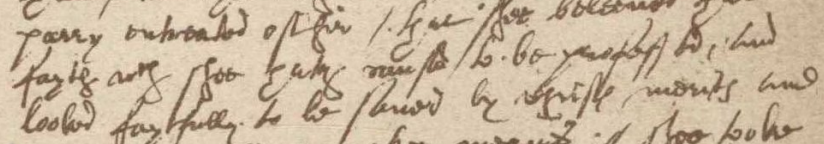

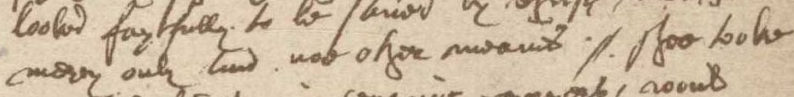

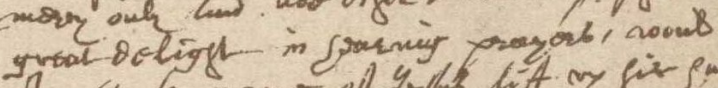

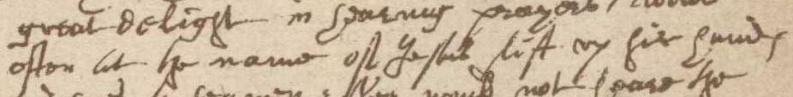

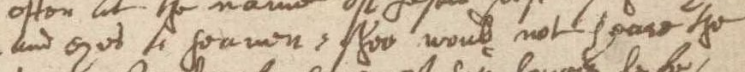

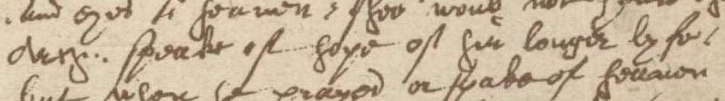

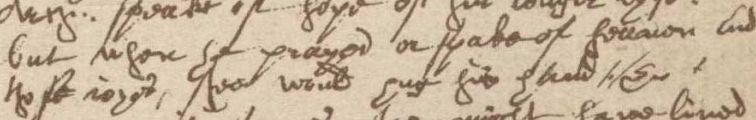

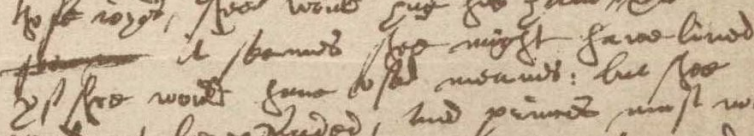

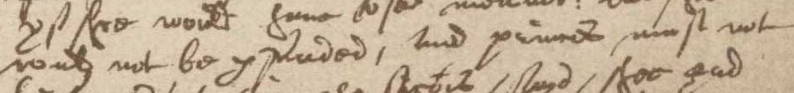

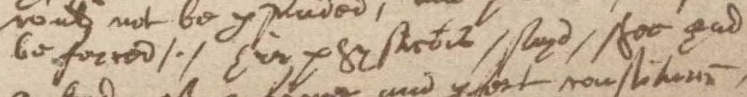

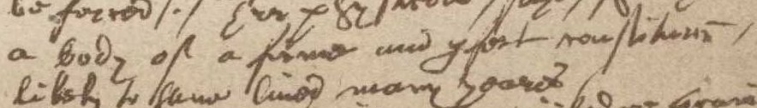

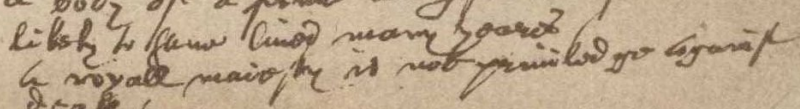

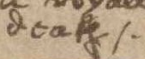

Harl. MS., Brit.Mus, No5353, fo. 117 . 


\section{IAR Y}

\section{OF \\ J OH N MA N N N GHAM, \\ OF THE MIDDLE TEMPLE,}

AND OF BRAD́BOURNE, KENT, BARRISTER-A'T-LAW,

1602-1603.

EDITED FROM THE ORIGINAL MANUSCRIPT BY

$$
\text { JOHN BRUCE, ESQ., }
$$

AND PRESENTED TO THE CAMDEN SOCIETY BY

WILLIAM TITE, ESQ., M.P., F.R.S., F.S.A.,

PRESIDENT OF THE SOCIETY.

WESTMINSTER:

PRINTED BY J. B. NICHOLS AND SONS.

M.DCCC.LX.VIII. 
W ESTMINSTFR :

J. B. NICHOLS AND SONS, PRINTERS,

25, PARLIAMENT STREET. 
To

\section{THE COUNCIL AND MEMBERS \\ oF}

\section{THE CAMDEN SOCIETY.}

\section{Gentlemen,}

When you did me the honour to appoint me President of your most useful Society as the successor of the Marquess Camden, I felt anxious to express my sense of that honour by some appropriate acknowledgment.

I at first thought of printing a MS. from my own library, but, not finding one that seemed exactly suitable, in my difficulty $I$ applied to my old and valued friend Mr. Bruce, and he pointed out to me Manningham's Diary in the British Museum as possessing a varied interest in the literary world which was likely to commend it to your notice. I willingly adopted his suggestion; and I owe to him my sincere acknowledgments for the pains he has bestowed in seeing the work through the press, and in prefacing it with an interesting essay.

I have now to offer you this copy of Manningham's little book, and to assure you how sincerely I am

Your obedient and obliged servant,

42, Lowndes Square,

WILLIAM TITE.

3rd October, 1868. 